\title{
Predicting Online Travel Adoption Intention of an Indian Consumer: A SEM-Neural Network Approach
}

\author{
Chakravarthi Koundinya \\ ICFAI Business School (IBS), The ICFAI Foundation for Higher Education (IFHE), Hyderabad, India \\ Email: dhakravarthik@ibsindia.org
}

How to cite this paper: Koundinya, C. (2019) Predicting Online Travel Adoption Intention of an Indian Consumer: A SEMNeural Network Approach. Theoretical Economics Letters, 9, 348-375. https://doi.org/10.4236/tel.2019.92026

Received: November 30, 2018

Accepted: February 23, 2019

Published: February 26, 2019

Copyright (อ 2019 by author(s) and Scientific Research Publishing Inc. This work is licensed under the Creative Commons Attribution International License (CC BY 4.0).

http://creativecommons.org/licenses/by/4.0/

\section{(c) (i) Open Access}

\begin{abstract}
Online channel has redefined the way businesses were conducted and many e-travel firms were the first to exemplify. The purpose of this paper is to determine the key factors that influence consumers' intention to adopt online channel for train travel. The extended model incorporates the basic ingredients of TAM, TPB and Shim's model along with several external variables such as trust, convenience and involvement. Data were collected from 514 online travel customers. In the first phase, structural equation modeling was employed to determine the significant variables and in the second phase, the neural network model was used to rank the relative importance of the significant predictors identified by SEM. The results indicated that Trust, Perceived Usefulness, Convenience and Website as significant factors. Among significant ones, neural networks suggested "convenience" as the highest importance. The study indicates few marketing approaches that can help travel service providers to formulate optimal marketing strategies.
\end{abstract}

\section{Keywords}

Online Ticketing, Online Travel, Neural Network Technology Adoption, Online Adoption Intention

\section{Introduction}

With new technological advancements and highly demanding customers, companies have been equipping themselves to provide superior customer experience as this being one of the main objectives in an online environment [1]. With internet disseminating huge information effectively and efficiently to all the stakeholders including customers, employees, shareholders and suppliers, internet as a medium became very predominant [2]. It was observed that higher the 
internet usage, higher the online shopping adoption [3]. With the changing dynamics among consumers turning more tech and internet-savvy, they have chance to experience better solutions [4]. Along with better experience, Consumer beliefs, opinions, perceptions, attitudes, trust, approach in embracing technology, value for convenience and one's risk taking ability all of these have made the situation more complex [5]. Internet usage in India has increased tremendously during the last decade with numbers soaring at 462 million by Jan 2018 [6]. Online Adoption intention is referred as the strength of the consumer's intention to perform specified purhasing behaviour over the online channel [7]. While consumer usage of the Internet for shopping is increasing, fewer people than anticipated actually purchase through the Internet [8]. As per [9], the online travel industry accounted for 54 percent share (Rs 1.10 lakh crore) of the digital commerce market, of which, domestic air ticket and railways booking continued to be among top contributors. Despite Indian railways adopting innovative means of promoting online ticketing, adoption is still not great and it's just around 58\% and the effort is now to increase purchase of e-tickets [10]. Therefore, with untiring attempts of IRCTC to shift all the consumers to online channel, it's important to explore the factors that influence the online ticketing adoption, as it would help travel service providers to create appropriate marketing strategies, leading to higher online adoption rates [11].

The present study addresses the existing research gap by developing new research model used to predict consumers' behavior. To make the study more comprehensive and unique, along with well-known predictors like perceived usefulness; trust; subjective norm; attitude, and as Chong et al., [12] suggested to extend with additional constructs, other relevant factors like convenience, website features, involvement, innovativeness etc., were considered in the study whose investigation was very limited till now. Hence the study's main objective is to determine the most significant factors that influence online adoption intention of train travel. Also, the relative importance of these factors was determined. With regular models like regression etc., only linear relations among variables are established. To resolve this issue, neural networks which is capable of modeling complex non-linear relationships is being used in the study.

The paper is organized into few sections: Section 2 dwells on the literature review of the studies on adoption intention of online channel with specific reference to online travel. Section 3 lists down the proposed hypotheses along with depiction of research model. Section 4 discusses the research methodology adopted in the study. Section 5 discusses the analysis of the data and the corresponding results, which includes output tables and figures. Section 6 provides the conclusions and Implications of the study where Summary, theoretical \& managerial implications. Section 7 puts forward the limitations and scope for future research.

\section{Literature Review}

In the technology adoption space, numerous studies have been carried out under 
the concepts of Technology Adoption Model-TAM [13], Diffusion of innovation-DOI [14], task-technology fit-TTF [15], Unified theory of acceptance and use of technology-UTAUT [16] and Theory of Planned Behaviour-TPB [17]. Though TAM proposed by Davis [13] was basis for most of the adoption models, it was often considered incomplete [18]. To better fill this incompleteness and predict consumer adoption, it was suggested to extend with additional constructs [12]. The present study analyses the influences of various external factors along with few consumer characteristics on adoption intention, away from most of the above mentioned traditional studies. Adoption Intention was often found to be the best predictor of behavior i.e., actual use of technology [19]. A model that was an extension of TPB was being proposed that will influence actual purchase in an online environment [20]. Behavioral intention reflects the individual's likelihood of engaging in the behaviour of interest. It measures how hard an individual is willing to take a specific action [21]. Numerous studies have been conducted addressing the technology adoption across various products [22] [23] where the influencing factors viz., Attitude, Innovativeness, Involvement, subjective norm, perceived usefulness, perceived risk, convenience, perceived ease of use, website design, trust have been identified. The present study was built based on understanding from Theory of planned behavior, Technology Adoption model, Theory of Reasoned Action, Model adopted by Kamarulzaman Y [24] with the influencing factors like website features, consumer trust, perceived risk, involvement, innovativeness, convenience. All these factors which have been tested independently and few in varied combinations across numerous studies [24]-[29] will be incorporated. Based on this, a new and a comprehensive model (shown in Figure 1) is being proposed to examine the Intention to adopt Online channel in the context of travel industry with specific reference Indian train travel service.

\section{Development of Hypotheses}

Adoption intention is defined as the strength of the consumer's intention to perform specified purhasing behaviour over the online channel [7]. It reflects the individual's likelihood of engaging in the behaviour of interest and measures how hard an individual is willing to take a specfic action [21]. In the present study, Adoption intention refers to the intention to adopt online channel for purhcasing. Numerous studies have been conducted addressing the technology adoption using "Adoption intention" as dependent variable across various products [13] [22] [23] [30] [31] [32], where many antecedents like trust, website features, subjective norm, perceived usefulness, etc., were identified.

\subsection{Website Features}

Websites intially used as a medium to provide information which later started offering goods and services for online sale and enabling online transactions for such sales. While Website features like content, text, pictures, graphics, layout, 


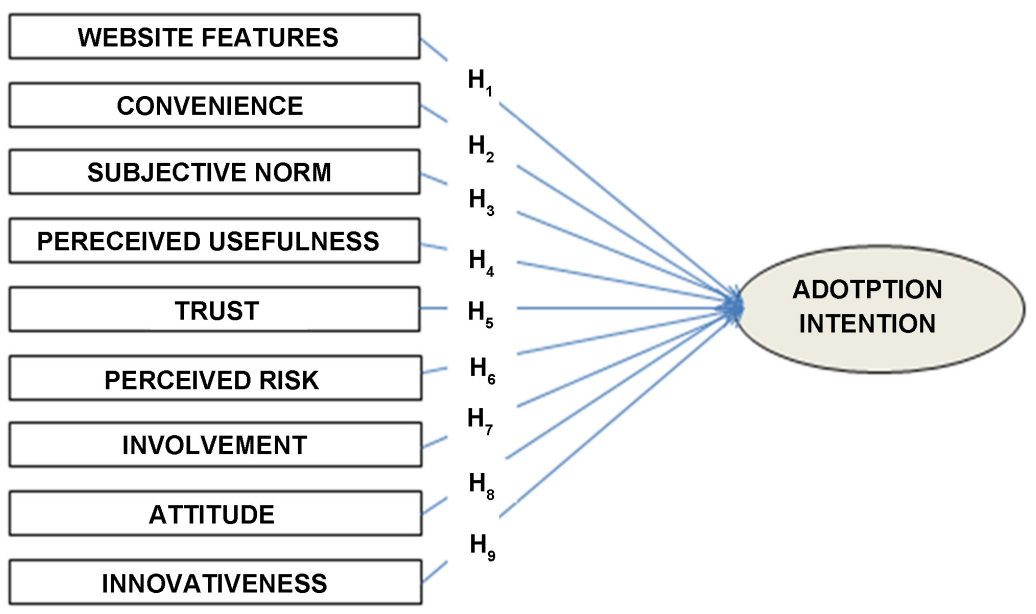

Figure 1. Research model.

sound, motion all these explored, how to convert web surfers into repeat visitors is a not well-understood [33]. It was identified that dimensions of effective website design lead to a higher likelihood of revisit and by providing richer media with more real environment has more positive influence with user's involvement [34]. Website design, navigation, information content, features become important for an online shopper and these website atmospherics cues were influencing site involvement, site attitude and online purchase intention as well as involvement in purchase decisions [35]. When compared with Browsers, buyers look website's interface and navigation very important features along with information quality, purchase information which support them to perform the purchase function smoothly [36]. With reference to travel websites, few existing websites are performing poor at "Personalisation" and "Playfulness" dimensions, which may influence the online adoption and inturn online atisfaction [37]. Consumers shift between online and offline channels as they proceed to purchase travel service. The shift among channels was always not with their choice, but sometimes with the obstacles they got via website [38]. But the most important benefit that website should provide was availability of website $\left(365^{\star} 24^{\star} 7\right)$ and saving time are important for consumers to buy ticket online [39]. Even to bring in consumers' trust to book online tickets, factors like authentication (certificates from Banks), providing privacy policy of website, and usage of secured technology in developing website [39]. Web user's willingness to stick to the travel website plays very important role driven by positive attitude and trust towards website [40]. Along with all these, even website brand [41] as well as attitude/positive beliefs [42], accurate information on product features, warranties, certification of websites, access to proper complaining process [43] acts as an important cue that will have influence on online purchase intention for e-travel services. Also, Brand recognition, Website look and feel, Navigation, Payment related issues, Presence of third party certification on website, Product description, About Us Page, Order tracking, Terms \& conditions, Money back guarantee, Customer reviews, Pop-up Ads, Logistics, Secure connection, Download time, Domain 
name, Discounts [44] along with relative advantages [45] influence online adoption or online purchase intention. Given such an impact website features have on online travel adoption, we propose the following hypothesis:

$\mathrm{H}_{1}$ : Website features have significant and positive effect on Adoption Intention of online train travel.

\subsection{Convenience}

Convenience is one of the important factors as internet offers a high degree of location-independent accessibility and maximizes purchase convenience and flexibility [46]. This is one reason why consumers use internet [47]. The concept of convenience is being defined as convenience in terms of time, effort, usage, place and acquisition, out of which saving time and effort with some flexibility in acquisition is suggested to be a convenient service [48]. Another definition of convenience concept was as a time-oriented construct, along with effort and space dimensions and consumers may get motivated by only one of these dimensions or all of them simultaneously [49]. Convenience has been considered as motivation to search and it is the one that is driving consumers to search more over the internet [50] and there are positive relationships between convenience and intention to search [51]. Customers right from web non-shoppers to E-shoppers perceive different kinds of convenience viz., energy, time, comparison etc., and their perceived convenience directly affects the frequency of online shopping [52]. Indian youth's preference to shop online was governed by the convenience, and it benefits them to browse for information [53]. Nevertheless, convenience is one of the significant factors [54]; primary shopping motivation [55] that influence customers' online shopping intention. "Convenience" is the primary motivation (98\%) that makes consumers to purhase products via e-stores [56]. But, it only benefits when communicated to consumers, like convenience of booking tickets round the clock, saving time consumers adopt online channels [57]. With reference to willingness to buy online in general, conveinience was the main factor [26] across students-28\% \& Nonstudents-31\% [58] and in e-ticketing as well [59]. But, conveneince was not influencing consumer attitudes on online purchasing [60]. The advantages of conveneince in the context of online train travel may motivate consumers to adopt online. Therefore, we propose the following hypothesis.

$\mathrm{H}_{2}$ : Convenience has significant and positive effect on Adoption Intention of online train travel.

\subsection{Subjective Norm}

Subjective norm defined as one's percetption of social normative pressures created by family, peers, friends and others' beliefs [61] and Social influence is the perception held by a person of what people who are significant to them, think their behaviour should be like Fishbein \& Ajzen [22]. Earlier research by Fishbein \& Ajzen [22] with the Theory of Reasoned Action model indicates "subjective norm" influences "attitude" which inturn impacts "Behavioral inten- 
tion". Later with Theory of planned behaviour by Icek Ajzen [17], the influence of subjective norm on behavioral intention was tested directly. The same has been followed by Soyeon Shim [20]. Subjective norm not only predicts information-seeking intention positively [62], but also influence online intention to purchase [63]. Even intention to reuse was influenced by subjective norm [64]. Numerous studies found Subjective norm having significant relationship with online purchase intention/Adoption intention [20] [65]. Even on e-ticketing typically travel service platforms, subjective norm has influence on Adoption intention [39]; usage of travel websites and e-travel services [42] [66]. With reference to e-ticketing across online reservation system, subjective norm was found significant [39], as well as influencing e-loyalty [25].

In contrast to the discussion above, subjective norm was not influencing Intention adoption [40] [67] [68] across online shopping as well in online travel transactions and in few cases there exists no or less influence [69]. With this opposing results across various studies, we propose to study the relationship between subjective norm and Adoption intention of online travel service with reference to train service. Hence, this hypothesis is indicated as

$\mathrm{H}_{3}$ : Subjective Norm has significant and positive effect on Adoption Intention of online train travel.

\subsection{Perceived Usefulness}

Perceived usefulness, defined as "the degree to which a person believes that using a particular system would enhance his or her job performance" Davis [13]. This was one of the variables discussed in Technology acceptance model-TAM by Davis [13] and trust was very important in the new technology acceptance. Perceived usefulness was found significant across many domains though tested intially for computer technologies and later on domains like adoption of banking technology [16] [70]; m-payment [71]. In the online shopping situations, pereceived usefulness was found to have significant influence on online shopping [43] [64] [72] [74] [75] [76]. Many a times, perceived usefulness along with perceived ease of use have been tested for their significance. Over the years it was identified that out of two independent variables in TAM model- "perceived usefulness" affects intended adoption of IT, whereas "perceived ease of use" failed most of the times [77]. Perceived usefulness (PU) influences intention to adopt online channel, but Perceived Ease of Use (PEOU) has many a times failed or identified insignificant [78]. When tested for searching and actual purchasing, "perceived usefulness" affects both the inquiry task as well as purchasing task in the online environment [77]. Once perceived usefulness remains high among customers, interfaces and online shopping information has value that helps in actual shopping [79]. In e-travel shopping as well, perceived usefulness has significant influence in adopting new technology [24], as well as intention towards online tickets purchase [39]. In certain instances across Indian e-travel as well as international e-travel, perceived usefulness influenced consumers' attitude which 
inturn had an impact on online adoption [80] [81] [82]. Perceived usefulness was not just limiting its influence on initial purchase intention, but also re-purchase intention [83]. Given this background of higher influence of perceived usefulness on adoption intention across online environments, we propose the following hypothesis.

$\mathrm{H}_{4}$ : Perceived usefuleness has significant and positive effect on adoption intention of online train travel.

\subsection{Trust}

Trust is the critical factor in stimulating purchases over internet [84]. One of the most important barriers for consumers to use internet to its full potential was because of lack of trust [85]. Trust is a feature of e-Commerce relationships that over a period of time deepens [86]. Unlike traditional retailers, in case of online retailers (e-vendors) it's a financial imperative to attract new customers as it is more expensive than traditional brick and mortar stores [87]. Trust differs the way consumers look at from that of vendors [88]. Maintaining customers' trust becomes the vital key to retain [87] and trust considered as the heart of relationships of all kinds [89] and it drives customers to make more transactions [40]. In an online environment, trust contribute significantly to "willingness to shop online" [26] and influences online shopping [90]. Online trust is not incidental and it is being influenced by factors like Brand recognition [91], Website look, feel, Navigation and such specific attributes [37]; Payment related issues, Presence of third party certification, Authentication [39], Order tracking, Terms \& conditions, Money back guarantee, Customer reviews, Secure connectionConfidence in using card [67], Past Experience [44] as well as privacy, communication \& security [92]. It was understood that the reason customers return to e-vendor were based on trust [77] and the technology is positively related to online trust [73] [74]. But few customers compare travel services online and purchase from traditional agents, whom they trust more [93]. Consumers on one hand look for confidentiality and on other hand demand synchronizing online trasactions across all touch points [94]. While online environment influences trust, the instances of trust influencing the attitude of online purchase intention were observed [81] [95] though conflicting in the case of Indian train ticketing service [80] as well as online repurhcase intention [83]. Trust is many times influenced inversely by perceived risk [41] and more specifically in online due to lack of face-to-face communication, which can be reduced by using software tools [96]. However, trust has been impacting online purchase intention in online shopping environment [68] [97] and also across specific online travel sites [24] [59] [64]. Since the impact of trust is found critical towards online purchase intention and with few studies focusing on general online shopping, we propose the following hypothesis with respect to online train travel adoption.

$\mathrm{H}_{5}$ : Trust has significant and positive effect on Adotpion intention of online train travel. 


\subsection{Perceived Risk}

Risk is a combination of uncertainty along with seriousness of outcome involved [98], and also indicated as the expectation of losses associated with purchase that trouble purchase behavior [99]. Perceived risk is an important indicator and should not be ignored by e-shoppers [46]. According to Lee, M.K.O \& Turban, E [100] perceived risk has been divided into two categories, one which is associated with products/services, and includes functional loss, financial loss, time loss, opportunity loss and product risk and the other associated with context to online transactions, and includes risk of privacy, security and non-reputation. Online channel which ranks better on perceived convenience is being troubled by perceived risk, which has strong negative influence on willing to purchase [101]. The kind of risks e-users perceive are security/privacy concerns, reluctance to use credit cards, preferences for in-store shopping, lack of product trial/inspection by hand [76] [102] along with fear of identity and financial theft and genuinity of the product [76]. Consumers have shown unwillingness to purchase online, primarily due to the risk they perceive in ecommerce [103]. One of the reasons consumers abandon shopping cart is perceived risk in e-transactions [104] as perceived risk reduces users' intentions to exchange information and complete transactions [105]. Attitude for online purchase is being influenced by perceived risk negatively, in turn affecting customer loyalty [106]. If referred by a friend, women buy online more compared to men as perceived risk reduces [107] and better education reduces perceived risks [91]. Perceived risk was negatively related to perceived usefulness \& perceived ease-of-use [72] as well as Attitude [80], Trust [41], all of these have been proved to influence adoption intetion. Nevertheless, more usage of website helps consumer overcome fear and confusion [27] and by enhancing privacy, data protection perceived risk can be addressed [73] [74]. Perceived risk reduces the lack of control which negatively influences e-commerce usage intentions [105]. With numerous studies [75] [101] [105] indicating that perceived risk has a negative relationship with online shopping, we propose to test the consumer behaviour in online travel ticketing environment and so the hypothesis is as follows.

$\mathrm{H}_{6}$ : Perceived risk has significant and negative influence on adoption of online train travel.

\subsection{Involvement}

Consumer involvement in purchase decision making process depends on needs, values and interests and it is defined as a person's perceived relevance of the object based upon inherent needs, values and interests [108]. Also, it can be referred as an enduring motivational propensity to engage in shopping [109]. With respect to online shopping, involvement is the degree of personal relevance or the interest of online shopping activities of that individual [108]. Involvement can be categorized as cognitive, individual and response based approaches [110] and both cognitive and affective involvement has significant influence on online 
purchase intention [111]. Involved consumers are likely to have longer stays at retail soters (Finn et al., 1994) and impacts behavior like spending more time, more frequent visits [112]. Similar behavior of long stays in an online environment has been observed indicating positive intention towards online store [113]. Online shoppers highly involved with a website are more willing to search information and explore new stimuli [114]. Interface design of an online retailer's site created vivid experience (i.e., sensory and behavioral experience similar to that with the actual product), affected consumer involvement with the online shopping [115] and it was proved correct in internet atmospherics research [35]. Basically the higher degree of involvement, the external variables impact on perceived ease of use and perceived usefulness tend to be higher [60]. With different types of involvement, better customer segmentation is possible [116]. In online shopping consumers have segmented as "Complex"; "Intelligent"; "Light"; and "Simple" [117] and across online travel services as "Moderate Enthusiasts", "Reluctant Purchasers", "Aficionados" and "Uninvolved" [118] so as to employ specific segment based strategies. The more the consumer involvement, the more online trust and less perceived risk making consumers use more travel e-shopping [24]. Therefore, we propose:

$\mathrm{H}_{7}$ : Involvement has significant and positive effect on Adotpion intention of online train travel.

\subsection{Attitude}

Consumer attitude has a major role to play in the adoption intention of online channel, initially proved by TAM model [13]. Attitude formation involves a combination of cognitive beliefs and Affective feelings about an object [119]. Attitude towards a certain object is formed, stored in memory and readily accessible which will not only ease decision-making process, but also enhance the quality of decision making [120]. Attitude was initially addressed in technology adoption spectrum by Fishbein \& Ajzen [22] in their Theory of reasoned action where attitude influences behavioral intention. Role of Attitude was addressed by Theory of planned behaviour [21], but when looked at the ability to explain attitude, TPB could explain $63 \%$ better than TAM model [40]. Consumer attitude is influenced by demographics, personal characteristics [121] as well as by factors like perceived advantages perceived usefulness [64] [82], perceived Ease of Use, perceived risk, Trust, compatibility and complexibility [39] [80] [95]. Attitude has been playing a significant role in influencing online purchase intention across online shopping portals [42] [57] [67] [68] [69] [81]; Not just influencing, attitude towards website motivates consumer to stick to the website leading to increased transactions of online travel services [40]. Consumers' past purchase behavior with the right attitude influence online purchase intention [67]. Attitude of consumer online shopping behaviour has mixed effects across, with Indian consumer having positive influence [43] while negative influence with jordanian consumers [65]. Attitude across older consumers on technology, payment mode etc., influence travel business [122]. With this review, an attempt 
is made to explore the influence of attitude on online adoption in travel service and so the hypothesis was proposed as...

$\mathrm{H}_{8}$ : Attitude has significant and positive effect on Adotpion intention of online train travel.

\subsection{Innovativeness}

Innovativeness is defined as one's willingness to try out new technology [123] and it's a personality trait that underlies the adoption of innovation [124] Trait is the basis of a stable trend over time; it varies among individuals and influences behavior [125]. Innovativeness is also defined as a desire to change, be innovative and try new things [126] [127]. Innovativeness is owned by all individuals at some point in one's lives [126] and Innovativeness appears to have a significant impact on adoption of new technologies [123] as well as acceptance of new products [128]. Innovativeness can be two forms namely, open processing innovativeness and domain specific innovativeness [3] which explain online adoption. Across genders of these two, domain-specific innovativeness was found to have the highest impact on internet shopping than open-processing innovativeness [129]. It was observed that in an online shopping environment, attitude was found significant among females while innovativeness among males [130]. Consumer innovativeness influences information search before buying products online and the decision to buy through the internet [3] [126] as well as online shopping success [79]. Innovativeness positively affects both perceived ease of use and perceived usefulness [130] and has a direct and positive influence on future online shopping intention [79]. Innovativeness also affects attitude which influences intention to search and purchase travel services online [69] and motivates to prefer shopping online [53]. The customers' readiness to adopt technology/rating of customers' innovativeness influence satisfaction and its attributes in an online environment [56] indicating the importance of innovativeness. In this context, we propose the following hypothesis

$\mathrm{H}_{9}$ : Innovativeness has significant and positive effect on Adotpion intention of online train travel.

Based on the review, research model was being proposed comprising of nine predictors of Adoption intention towards online travel, shown in the Figure 1.

\section{Research Methodology}

\subsection{Data Collection and Sample}

The data was collected from those who use online channel for booking their train tickets. In the first phase with a sample of 100 online users, a pilot study was carried out to refine the statements used in the questionnaire, wherein test for validity and reliability were also executed. Based on the pilot study phase 2 study was carried out with a sample of 514 online users who book train tickets through internet as medium. A sample of 729 internet users have been identified using purposive sampling method (respondents using internet who have pur- 
chased train tickets during past 6 months using their own credit/debit card/wallet), of which 514 respondents who book online train tickets were asked to fill the questionnaire. Demographic structure of the sample is shown Table 1.

\subsection{Measurement of Variables}

The conceptual model for research included nine independent variables and one dependent variable. Each variable is being measured by 3 to 4 statements making it a total of 30 in all which were rated by respondents on a five point likert scale (score 1 indicates strong disagreement with the statement, while the score 5 indicates strong agreement). All the statements identified are being selected from the review of literature and the source of such items is being indicated in the Table 2.

\section{Data Analysis and Results}

\subsection{Reliability and Validity Analysis}

In the present study, the entire data analysis was carried out in three steps. Initially as a part of first step, to make the study appropriate, along with reliability

Table 1. Demographic profile of the respondents.

\begin{tabular}{|c|c|c|c|c|c|}
\hline & & \multicolumn{2}{|c|}{ Internet Users } & \multicolumn{2}{|c|}{$\begin{array}{l}\text { Online Ticket } \\
\text { Booking Users }\end{array}$} \\
\hline \multicolumn{2}{|c|}{ Demographic Variable } & NUMBER & $\%$ & NUMBER & $\%$ \\
\hline \multirow{4}{*}{ Age } & Below 20 Years & 15 & 2.1 & 10 & 1.9 \\
\hline & 20 - 30 Years & 447 & 61.3 & 305 & 59.3 \\
\hline & $31-50$ Years & 246 & 33.7 & 188 & 36.6 \\
\hline & Above 50 Years & 21 & 2.9 & 11 & 2.1 \\
\hline \multirow{3}{*}{ Gender } & Male & 582 & 79.4 & 416 & 80.9 \\
\hline & Female & 147 & 20.6 & 98 & 19.1 \\
\hline & Government & 72 & 9.9 & 53 & 10.3 \\
\hline \multirow[t]{3}{*}{ Profession } & Private & 519 & 71.2 & 371 & 72.2 \\
\hline & Self Employed/Business & 138 & 18.9 & 90 & 17.5 \\
\hline & Lower Or Junior Level & 153 & 21.0 & 94 & 22.2 \\
\hline \multirow{2}{*}{$\begin{array}{c}\text { Position In } \\
\text { Organization }\end{array}$} & Middle Level & 358 & 49.1 & 270 & 63.7 \\
\hline & Senior Level & 80 & 11 & 60 & 14.1 \\
\hline \multirow{2}{*}{ IT Professional } & IT Professional & 128 & 17.6 & 98 & 19.1 \\
\hline & NON-IT Professional & 463 & 63.5 & 326 & 63.4 \\
\hline Highest & Under Graduate & 67 & 9.2 & 24 & 4.7 \\
\hline \multirow{3}{*}{$\begin{array}{c}\text { Education } \\
\text { Qualification }\end{array}$} & Graduate & 256 & 35.1 & 166 & 32.3 \\
\hline & Post-Graduation \& above & 406 & 55.7 & 324 & 63.0 \\
\hline & Below 20,000 & 292 & 40.1 & 165 & 32.1 \\
\hline \multirow{3}{*}{ Income Levels } & 20,000 to 50,000 & 304 & 41.7 & 236 & 45.9 \\
\hline & Above 50,000 & 133 & 18.2 & 113 & 22.0 \\
\hline & Total & 729 & 100 & 514 & 100 \\
\hline
\end{tabular}

Source: primary data. 
Table 2. Items used in questionnaire.

\begin{tabular}{cc}
\hline Perceived Usefulness & $\begin{array}{c}\text { Adams et al.,(1992); David Gefen et al. [77]; } \\
\text { Lgbaria } \text { et al., (1996) }\end{array}$ \\
\hline Attitude & $\begin{array}{c}\text { Sorce et al., (2005); Limayem Et Al (2000) } \\
\text { Convenience } \\
\text { Perceived Risk }\end{array}$ \\
Website Features & Hassan et al., (2006) \\
Trust & (Aladwani And Palvia, 2002) \\
Innovativeness & Gefen And Straub [7] \\
Subjective Norm & Goldsmith And Hofacker [126]; And Citrin et al. [3] \\
Involvement & (Shih And Fang, 2004). \\
Adoption Intention & Young et al. [117]; Jean And Gilles [109] \\
(dependent variable in this study) & Kim And Park (2005); Shim et al. [20] \\
\hline
\end{tabular}

test, validity test was being carried out and final statements for each variable were arrived. Once reliability \& validity was tested, structural equation modeling using AMOS (SPSS) was used to test the test hypotheses. Later, an attempt was made to test the independent variables which were found significant in SEM (structural equation model) analysis on their importance in showing effect on dependent variable-Online travel adoption intention.

Based on the Cronbach's alpha coefficient, each constructs' internal consistency of the items and the reliability was identified, the results of which are shown in Table 3. Reliability results for all the variables crossed the threshold figure which is 0.7 [131]. The values of cronbach's alpha were in the range of 0.701 to 0.901 , indicating better reliability. The highest alpha value was for the variable "Innovativeness" whereas the lowest was for "trust".

The Inter-correlation matrix across different variables and the values of average variance extracted (AVE) along with composite reliability (CR) of each component is being explained in Table 4. It was found that all the variables are with AVE values higher than 0.5 (threshold value), thus confirming the convergent validity of the model [132]. At 0.5 level of significance, the confirmatory factor loadings of all the constructs exceeded 0.63 mark. It was identified that the average variance extracted value of each structure is higher than the squared correlation coefficient between the given and other structures which supported discriminant validity. It was observed that one of the variables "perceived risk" has either negative or low correlation with other variables indicating its negative influence on all others. The values of composite reliability (CR) of all structures exceeded 0.6, which is a good sign [133].

The second phase of analysis was carried out using Structural Equation Modeling using AMOS. The results of SEM, basically the measures goodness-of-fit indices were analyzed to understand the proposed model fit, explained in Table 5. Model's final overall goodness to fit also been provided below in the table.

Explaining Antecedents of "Adoption Intention": The study carried out brings out the importance of antecedents that influence consumers' online purchase 
Table 3. Reliability analysis.

\begin{tabular}{cc}
\hline Variables & cronbach's $\alpha$ \\
\hline Website & 0.832 \\
Innovativeness & 0.901 \\
Perceived Risk & 0.889 \\
Attitude & 0.812 \\
Subjective Norm & 0.809 \\
Convenience & 0.771 \\
Perceived usefulness & 0.835 \\
Trust & 0.701 \\
Intention & 0.728 \\
Involvement & 0.848
\end{tabular}

Table 4. Inter-correlation matrix, AVE and CR.

\begin{tabular}{|c|c|c|c|c|c|c|c|c|c|c|}
\hline & 1) Convenience & $\begin{array}{l}\text { 2) Website } \\
\text { Features }\end{array}$ & $\begin{array}{l}\text { 3) Perceived } \\
\text { Usefulness }\end{array}$ & $\begin{array}{l}\text { 4) Perceived } \\
\text { Risk }\end{array}$ & $\begin{array}{l}\text { 5) Subjective } \\
\text { Norm }\end{array}$ & 6) Trust & 7) Attitude & $\begin{array}{l}\text { 8) Innovat- } \\
\text { iveness }\end{array}$ & 9) Involvement & $\begin{array}{l}\text { 10) Online } \\
\text { Intention }\end{array}$ \\
\hline 1 & 1 & & & & & & & & & \\
\hline 2 & 0.506 & 1 & & & & & & & & \\
\hline 3 & 0.644 & 0.534 & 1 & & & & & & & \\
\hline 4 & -0.007 & 0.041 & 0.098 & 1 & & & & & & \\
\hline 5 & 0.404 & 0.388 & 0.367 & 0.084 & 1 & & & & & \\
\hline 6 & 0.600 & 0.583 & 0.657 & -0.013 & 0.324 & 1 & & & & \\
\hline 7 & 0.683 & 0.552 & 0.693 & 0.068 & 0.554 & 0.698 & 1 & & & \\
\hline 8 & 0.359 & 0.439 & 0.420 & 0.172 & 0.394 & 0.545 & 0.415 & 1 & & \\
\hline 9 & 0.502 & 0.588 & 0.553 & 0.055 & 0.387 & 0.650 & 0.606 & 0.566 & 1 & \\
\hline 10 & 0.666 & 0.508 & 0.690 & -0.031 & 0.439 & 0.702 & 0.726 & 0.432 & 0.561 & 1 \\
\hline AVE & 0.58 & 0.65 & 0.66 & 0.80 & 0.62 & 0.56 & 0.65 & 0.77 & 0.70 & 0.61 \\
\hline CR & 0.64 & 0.70 & 0.71 & 0.82 & 0.67 & 0.63 & 0.70 & 0.79 & 0.73 & 0.66 \\
\hline
\end{tabular}

Table 5. Model Fit Indices for Path Diagram.

\begin{tabular}{ccc}
\hline Item & Recommended Value & Measured Value \\
\hline Minimum Chi-Square Value-(CMIN)/DF & $<5$ - Acceptable & 2.268 \\
Comparative Fit Index-CFI & $>0.90$ & 0.912 \\
Goodness To Fit Index-GFI & $>0.90$ & 0.821 \\
Relative Fit Index-RFI & $>0.90$ & 0.920 \\
Normed Fit Index-NFI & $>0.90$ & 0.844 \\
Tucker Lewis Index-TLI & $>0.90$ & 0.823 \\
Root Mean Square Residual-RMR & $<0.02$ & 0.031 \\
Root Mean Square Error Of Approx-RMSEA & $<0.05$ & 0.076 \\
\hline
\end{tabular}


intention of train tickets. Of all the determinants, "Trust" and "Perceived usefulness" were the major determinants of consumers' online purchase intention while purchasing train tickets online. These results give us an indication of decent exploratory power of the model explaining the online purchase intention of the consumers while purchasing train tickets in India. The Comparative Fit Index-CFI (0.912) is a good value and is nearing the recommended value of 0.90 \& above; with Goodness to Fit index-GFI (0.821) also nearing to the recommended value of $0.90 \&$ above. The values of Relative Fit index-RFI (0.92); Normed Fit Index-NFI (0.844); \& Tucker Lewis Index-TLI (0.823) gives near to good values of the recommended ones. MINIMUM CHI-SQUARE VALUE(CMIN)/df value of Default model was at 2.268, which indicates a good one as it is within the range (2 3 ) indicating a good fit, when highest limit is " 5 ”. Root Mean Square Residual-RMR value was 0.031 which is near to the recommended value of 0.02; Root Mean Square Error of Approximation-RMSEA is equal to 0.076, which is above the recommended level of less than 0.05 and below highest level of 0.08 . All these results indicate that model is a marginally a good fit model given the context (Table 6).

\subsection{Structural Equation Modeling for Verifying the Relationships of the Model}

\subsubsection{Significant Results of the Model}

Model suggests that Trust of the consumer on online channel (path coefficient = 0.56 and $p=0.000$ ) has a significant and strong influence on the consumers' online purchase intention. This implies that the more service provider bestow trust in the online transaction environment, consumer will be more interested to purchase train tickets through online.

Perceived usefulness has a significant a strong influence on online purchase intention (path coefficient $=0.54, \mathrm{p}=0.000$ ). This result indicate us that Consumers have inclination to accept if the technology is useful and if the transaction of purchasing train tickets is an easier activity. The other construct that was

Table 6. Hypothesized Relationships.

\begin{tabular}{lccc}
\hline \multicolumn{1}{c}{ Hypotheses } & Estimates & C.R. & Sig. \\
\hline $\mathrm{H}_{1}:$ Attitude $\longrightarrow$ Adoption intention & 0.25 & & $*$ \\
$\mathrm{H}_{2}:$ Trust $\longrightarrow$ Adoption intention & 0.56 & 3.125 & $* *$ \\
$\mathrm{H}_{3}:$ Perceived Usefulness $\longrightarrow$ Adoption intention & 0.54 & 2.958 & $* *$ \\
$\mathrm{H}_{4}:$ Convenience $\longrightarrow$ Adoption intention & 0.40 & 2.125 & $* *$ \\
$\mathrm{H}_{5}:$ Website $\longrightarrow$ Adoption intention & 0.35 & 1.189 & $* *$ \\
$\mathrm{H}_{6}:$ Perceived risk $\longrightarrow$ Adoption intention & -0.17 & 1.156 & $*$ \\
$\mathrm{H}_{7}:$ Innovativeness $\longrightarrow$ Adoption intention & 0.04 & 0.564 & $\mathrm{~ns}$ \\
$\mathrm{H}_{8}:$ Involvement $\longrightarrow$ Adoption intention & 0.28 & 0.408 & $\mathrm{~ns}$ \\
$\mathrm{H}_{9}:$ Subjective Norm $\longrightarrow$ Adoption intention & 0.14 & 0.250 & $\mathrm{~ns}$ \\
\hline
\end{tabular}

${ }^{*} 0.01$ of significance; ${ }^{*} 0.1$ of significance; ns- not significant. 
found having a strong influence on online purchase intention was Convenience. With (path coefficient $=0.40 \& \mathrm{p}=0.00$ ), convenience has been identified as one of the strong predictor of consumers' online purchase intention. This indicates that consumers' intention to purchase train tickets online increases if there is a convenience in saving physical effort, round the clock transaction and less wastage of time. Also, it was found that Website features (with path coefficient = $0.35 \& \mathrm{p}=0.000)$ has good influence on online purchase intention. Website accessibility, navigability, authentication of the transactions does have a great importance among consumers and which have an influence on online purchase intention.

Model also indicated that Perceived Risk has negative influence on Online purchase intention (path coefficient $=-0.17$ and $p=0.012$ ), but it was found significant indicating that Perceived risk influences online purchase intention negatively. This result proposes that consumers' weak opinions on online channel security, trustworthiness of service provider have an influence on online purchase intention and also in a negative manner.

\subsubsection{Insignificant Results}

Model indicated that Consumer Innovativeness has a weak and insignificant influence on Online purchase intention (path coefficient $=0.04$ and $\mathrm{p}=0.082$ ). The study shows that the consumer innovativeness does not play an important role in determining consumers' online purchase intention. "Subjective Norm" was one variable that was found insignificant indicating that the consumers approach towards online travel adoption is not based on what others think about users' act.

Also, Consumer involvement was found to be insignificant (with path coefficient $=0.28$ and $p=0.242$ ). This indicates that consumer do not have any pleasure, enjoyment or serious involvement in process of online purchase of train tickets.

\subsection{Neural Network Analysis for Predicting Online Travel Adoption}

As defined by Haykin [134], artificial neural network is massively parallel distributed processor made up of numerous processing nodes (similar to the human brain) and these processing units can store experimental knowledge. Hence, based on this a neural network model is prepared which can be tested for varied input data. Neural network, because of its ease of use, power and flexibility this tool is considered to be one of the good tools for any kind of predictive analysis. In the present study, the researcher has used multilayer perceptron in SPSS package for analysis.

From the past research, it was understood that few conventional linear statistical techniques like Multiple regression and SEM are able to detect only linear relationships, which may lead to over-simplification of complex decision making processes. With the traditional existing tools like multiple regression and struc- 
tural equation modeling identifying linear relationships, it becomes difficult to address complex analysis and decision making [135]. Hence, the researcher has used the artificial neural network to analyze the travel adoption pattern through training sets and using testing sets the prediction can be carried out.

Based on the past studies, it was understood that in the technology acceptance neural network models, usually one hidden layer is being used [135] [136] [137] [138]. In our research, neural network is modeled using SPSS 20 with six independent variables, which are identified as significant by SEM (i.e., Perceived Usefulness, Trust, Convenience, Attitude, Perceived risk and Website features) and "Adoption Intention" as one output variable. The researcher in the present study has used one hidden layer while analyzing the data. In order to avoid over-fitting, a ten-fold cross validation was being carried out with $90 \%$ of data used for training and $10 \%$ for testing which helps to measure the prediction accuracy of training network [135] [136] [137] [138]. The mean RMSE for the training network stood at 0.1020 with minimal standard deviation of 0.0016 , while the testing network at 0.0953 and 0.0096 respectively. These figures emphasized the accurate prediction capability of the model. The minimal RMSE (Table 7) values indicate higher accuracy in prediction [135] [138].

The Neural network model also predicts the importance of every independent variable and the values are shown in Table 8 . This indicates which of the variables played the most important role in predicting the consumers' adoption of online travel. The results indicate "convenience" at high importance followed by "attitude, perceived usefulness and trust". The independent variables "website features" and "perceived risk" are of minimal importance though found significant.

\section{Conclusions}

\subsection{Summary of the Study}

This research presents a new model in an online travel environment and examined the relationships between nine potential predictors of Adoption intention (website features, convenience, subjective norm, perceived usefulness, trust, perceived risk, involvement, attitude and innovativeness). A sequential, multi-method approach was adopted integrating structural equation modeling (SEM) and the neural network analysis. The model includes importance of consumer involvement, perceived risk and innovativeness in predicting adoption intention while using online channel for purchasing train travel service along with those variables that recommend usability (convenience, perceived usefulness, website features). The results indicate that in the presence of usability factors, few of the consumer characteristics (involvement, innovativeness and subjective norm) failed to show their influence on Adoption intention in train travel service. With trust being high influential factor followed by perceived usefulness, convenience and website features in that order, it's evident that usability scores over personal factors in online travel purchase. 
Table 7. RMSE values for the neural networks.

\begin{tabular}{ccc}
\hline Neural Network & Training & Testing \\
\hline ANN1 & 0.1019 & 0.0997 \\
ANN2 & 0.1031 & 0.0859 \\
ANN3 & 0.1052 & 0.0962 \\
ANN4 & 0.1029 & 0.0801 \\
ANN5 & 0.1002 & 0.0978 \\
ANN6 & 0.1012 & 0.0992 \\
ANN7 & 0.1011 & 0.0947 \\
ANN8 & 0.1028 & 0.0891 \\
ANN9 & 0.1001 & 0.1161 \\
ANN10 & 0.1013 & 0.0945 \\
Mean & 0.1020 & 0.0953 \\
Standard deviation & 0.0016 & 0.0096 \\
\hline
\end{tabular}

Table 8. Independent variable importance.

\begin{tabular}{ccc}
\hline & Importance & Normalized Importance \\
\hline CONVENIENCE & 0.218 & $100.0 \%$ \\
WEBSITE FEATURES & 0.078 & $35.9 \%$ \\
PERCEIVED USEFULNESS & 0.210 & $96.5 \%$ \\
PERCEIVED RISK & 0.085 & $38.9 \%$ \\
TRUST & 0.195 & $89.7 \%$ \\
ATTITUDE & 0.214 & $98.4 \%$ \\
\hline
\end{tabular}

This study combined the application of Structural equation modelling and neural networks, a new approach in order to arrive at more appropriate results. The final results of this combination also helped in arriving at the importance of variables among those found significant in the entire prediction process.

\subsection{Theoretical Implications}

This research contributes to the existing technology adoption studies carried out in the travel service environment again with a new methodology by integrating neural networks with SEM approaches. This research integrates SEM and neural network approaches making it one of the kind study representing Indian train travel service. While SEM was able to identify the causal relationships, neural network's prediction capabilities in a non-linear complex situations made this study interesting. At the same time, using only neural networks might not provide causal analysis and with hidden layers in the network black box makes it more ambiguous across training and testing datasets. This model while supporting the previously proved TAM, TPB \& TRA (Theory of Reasoned Action) 
models has added new dimensions like convenience, consumer innovativeness, involvement, website features, trust and subjective norm, which have high relevance in this modern environment. All these attributes though were important even in earlier decades; but their relevance has multifold in this era of tech-driven human lives.

The present study contributes to the existing knowledge in several ways. In the recent past, there has been research carried out examining the adoption intention of online channel across travel services, but this study specifically attempted to bring out predictors of adoption intention with reference to online purchase of train travel service among Indian consumers. Along with variable "Perceived usefulness", a new dimension of technology benefit factor "convenience" is being tested and was being proved to have significant influence on adoption intention. This new variable "convenience" which describes the consumers' benefit little away from technology usefulness has been identified to be having highest importance among all significant predictors. A similar result was confirmed in the studies conducted by Athiyaman [26] [57]. Surprisingly, the variables "Innovativeness" and "involvement" were found insignificant. But studies conducted few years back, where online usage was considered to be a special trait driven by consumer involvement and innovativeness, many a times they were proved to be the important predictors of adoption intention [3] [24] [34] [69] [111] [123] [126]. As consumers' learning curve shifted phases online usage was no more a trait driven by consumer innovativeness or involvement rather, it became a day-to-day norm that consumer is expected to use online channel involuntarily. The influence of these variables is more diluted in the services where the satisfaction from online purchasing channel was not a serious contributor in the overall satisfaction of consumption engagement. Also, subjective norm's role in new age online purchase has very minute influence on today's consumer purchasing behaviour. The same has been confirmed by studies [40] [67] [68]. It is worth pointing out that even among the tech-savvy consumers, Trust was found to be highest influencer among all the predictors of adoption intention in train travel service purchase process. The lesser the trust on online purchase process, the higher the perceived risk consumer experiences. The results also indicate that one of the predictors "perceived risk" found to be of high significance and the importance levels (38.9\%) suggests no ignorance of the attributes that contributes to perceive risk. This result indicates the influence of the risk attribute even among today's modern consumers, which has been identified similar across the studies [41] [75] [101].

\subsection{Managerial Implications}

The findings of the present study can be useful for the train travel service provider in India, irctc.com in further strengthening in the online booking of train services. Indian railways with its portal irctc.com, is one of the prominent travel sites succeeded in diverting consumers to online channel for booking train tickets, though still $66 \%$ of them still use traditional channels. 
The study concludes to indicate that the "Trust" and its prerequisites need to be addressed as it influences online travel service much. Any less quantum of trust among consumers automatically increases the presence of "perceived risk", which also needs to be tackled with the similar gravity. Few implications to the practicing managers include the measures that they need to take to counter perceived risk and generate trust include few like... a) Safe custody of consumers' personal/financial information of being getting mismanaged. b) Online channel to promise the similar quality solution similar to that of any kind of physical channel. c) Measures to address fear and anxiety of consumers by managing own professional blogs. d) Processes that give more confidence and enhance trust should be practiced like immediate issue of a "credit note" if money got deducted while ticket was not booked. e) Payment gateways, available in various forms shall of being of high credentials which can reduce the anxiety and fear of money getting lost.

Another important predictor was "perceived usefulness" that was influencing Adoption intention need due attention. Consumers should be able to assess the incremental benefit of online adoption against the traditional channels, may be need to address ease of using online channel. May be few greeters handholding the consumers who visit traditional channel and rewarding the shift could boost the online train ticket booking. These measures that indicate benefits need also effective communication so as to persuade consumers for desired action.

Convenience, the next most valued antecedent after trust and perceived usefulness was considered to be consumers' most cherished benefit. All the touch points need to communicate the consumers about the saving of time, physical and monetary efforts as well as far-flung consumption of travel service. One of the important determinants of online purchase intention of train tickets is Website and there is a huge importance required for the web interface service provider manages. Navigating through the website, round the clock accessibility, Bounciness of the web, safety and security as well as quality of the content, etc., have direct influence on the consumers' motivation to book train tickets online. Service provider's web SST should encourage more consumers to visit, search, compare and finally consume the service. Consumers' attitude is another prominent antecedent that influence adoption intention of online travel service, which if dealt properly leads to greater results. Attitude needs to be nurtured methodically across numerous complementary touch points in order to generate incremental positive motivation for online adoption.

It's a challenge for travel service provider to address diverse behavior of various customer groups/cluster. A kind of a customer groups exists who do not own online banking account or credit/debit cards or there is any issue with ID authenticity-referred as Cluster \# 1 . Train travel service provider needs to introduce its own wallet (prepaid/credit) which works on online login ID. This increases a lot the consumers' propensity to involve in online ticketing process. Second set of consumers are there who have the required infrastructure, but worried about risk of being cheated or misuse of data-referred as Cluster \#2. A 
wide variety of trust increasing measures need to be adopted for these consumers to join the wagon. A kind of an eccentric customer group exists who do not want to try or use or even learn online transaction process-referred as Cluster \# 3. To address this cluster, travel service provider needs to organize demos across residential premises, working locations, ticket booking counters, factories etc.

\section{Limitations and Scope for Future Research}

One of the main limitations was that the study is specific to consumers in metros of Indian train travel service and so need to be cautious in generalizing. Study has not considered customer groups like students or homemakers who use online ticketing using their family members' wallets/cards. The questionnaire, methodology though was tested for its reliability; it needs to be adopted with caution. Future research should look forward in comparing the proposed model across rural and urban\& other demographics; medium of technologies as internet penetration has been increasing exponentially.

\section{Conflicts of Interest}

The author declares no conflicts of interest regarding the publication of this paper.

\section{References}

[1] Chang, S.H., Chih, W.H., Liou, D.K. and Yang, Y.T. (2016) The Mediation of Cognitive Attitude for Online Shopping. Information Technology \& People, 29, 618-646. https://doi.org/10.1108/ITP-08-2014-0172

[2] Violin, B. (1996) The Biggest and Best. Information, 9/9, 44-46.

[3] Citrin, A.V., Sprott, D.E., Silverman, S.N. and Stem Jr., D.E. (2000) Adoption of Internet Shopping: The Role of Consumer Innovativeness. Industrial Management \& Data Systems, 100, 294-300. https://doi.org/10.1108/02635570010304806

[4] Immonen, M. and Sintonen, S. (2015) Evolution of Technology Perceptions over Time. Information Technology \& People, 28, 589-606.

https://doi.org/10.1108/ITP-12-2013-0219

[5] Anite Travel Systems' Online Travel Surve (2000) International Journal of Retail \& Distribution Management, 29, 9.

[6] Statista (2018) Number-of-Internet-Users-in-the-Asia-Pacific-Region. https://www.statista.com/statistics/265153/number-of-internet-users-in-the-asia-pa cific-region/

[7] Salisbury, W.D., Pearson, R.A., Pearson, A.W. and Miller, D.W. (2001) Perceived Security and the World Wide Web Purchase Intention. Industrial Management and Data Systems, 101, 165-177. https://doi.org/10.1108/02635570110390071

[8] PEW Research Center (2008) Trends in Online Shopping. http://www.pewinternet.org/2008/02/13/part-1-trends-in-online-shopping/

[9] CXOtoday (2018) Travel, E-Com, Utility Lead To India’s Digital Commerce Boom: Study.

http://www.cxotoday.com/story/travel-e-tail-utility-lead-to-indias-digital-commerc e-boom-study/ 
[10] Business Standard (2016) No Transaction Fee on Card Payments, Rail e-Ticketing Till Dec 31.

https://www.business-standard.com/article/news-ians/no-transaction-fee-on-card-p ayments-rail-e-ticketing-till-dec-31-116112300726_1.html

[11] Chan, F.T.S. and Chong, A.Y.L. (2012) A SEM-Neural Network Approach for Understanding Determinants of Interorganizational System Standard Adoption and Performances. Decision Support Systems, 54, 621-630. https://doi.org/10.1016/j.dss.2012.08.009

[12] Chong, A.Y.-L., Chan, F.T.S. and Ooi, K.-B. (2012) Predicting Consumer Decisions to Adopt Mobile Commerce: Cross Country Empirical Examination between Chinaand Malaysia. Decision Support Systems, 53, 34-43. https://doi.org/10.1016/j.dss.2011.12.001

[13] Davis, F.D. (1989) Perceived Usefulness, Perceived Ease of Use, and User Acceptance of Information Technology. MIS Quarterly, 13, 319-340.

https://doi.org/10.2307/249008

[14] Rogers, E.M. (1962) Diffusion of Innovations. Free Press, New York.

[15] Goodhue, D. and Thompson, R. (1995) Task-Technology Fit and Individual Performance. MIS Quarterly, 19, 2. https://doi.org/10.2307/249689

[16] Venkatesh, V., Morris, M.G., Davis, G.B. and Davis, F.D. (2003) User Acceptance of Information Technology: Toward a Unified View. MIS Quarterly, 27, 425-478. https://doi.org/10.2307/30036540

[17] Ajzen, I. (1991) The Theory of Planned Behavior. Organizational Behavior and Human Decision Processes, 50, 179-211. https://doi.org/10.1016/0749-5978(91)90020-T

[18] Brown, S.A. and Venkatesh, V. (2005) Model of Adoption of Technology in Households: A Baseline Model Test and Extension Incorporating Household Life Cycle. MIS Quarterly, 29, 399-426. https://doi.org/10.2307/25148690

[19] Zhang, L., Zhu, J. and Liu, Q. (2012) A Meta-Analysis of Mobile Commerce and the Moderating Effect of Culture. Computers in Human Behavior, 28, 1902-1911. https://doi.org/10.1016/j.chb.2012.05.008

[20] Shim, S., Eastlick, M.A., Lotz, S.L. and Warrington, P. (2001) An Online Prepurchase Intentions Model: The Role of Intention to Search. Journal of Retailing, 77, 397-416. https://doi.org/10.1016/S0022-4359(01)00051-3

[21] Ajzen, I. and Fishbein, M. (1980) Understanding Attitudes and Predicting Social Behavior. Prentice-Hall, Englewood Cliffs.

[22] Fishbein, M. and Ajzen, I. (1975) Belief, Attitude, Intention and Behavior: An Introduction to Theory and Research. Addison Wesley, Reading.

[23] San-Martín, S. and Camarero, C. (2012) A Cross-National Study on Online Consumer Perceptions, Trust, and Loyalty. Journal of Organizational Computing and Electronic Commerce, 22, 1-23. https://doi.org/10.1080/10919392.2012.642763

[24] Kamarulzaman, Y. (2007) Adoption of Travel E-Shopping in the UK. International Journal of Retail \& Distribution Management, 35, 703-719. https://doi.org/10.1108/09590550710773255

[25] Mouakket, S. and Al-hawari, M.A. (2012) Examining the Antecedents of E-Loyalty Intention in An Online Reservation Environment. Journal of High Technology Management Research, 23, 46-57. https://doi.org/10.1016/j.hitech.2012.03.005

[26] Prasad, C.J. and Aryasri, A. (2009) Determinants of Shopping Behaviour in E-Tailing: An Empirical Analysis. Paradigm, 13, 73-83. 
https://doi.org/10.1177/0971890720090110

[27] Belanche, D., Casaló, L.V. and Guinalíu, M. (2012) Website Usability, Consumer Satisfaction and the Intention to Use a Website: The Moderating Effect of Perceived Risk. Journal of Retailing and Consumer Services, 19, 124-132. https://doi.org/10.1016/j.jretconser.2011.11.001

[28] Sahil, K. and Ali, E. (2017) A Systematic Review of Technology Adoption Frameworks and Their Applications. Journal of Technology Management \& Innovation, 12, 106-113. https://doi.org/10.4067/S0718-27242017000400011

[29] K. K. Ramachandran, D.P. (2012) A Study on The Customer Perception, Preference and Satisfaction towards Online Traveling. European Journal of Social Sciences, 33, 163-183.

[30] Chen, H.Q., Wang, H. and Liu, L. (2017) Research on the Influence of Recommended Sources on the Adoption Intention in Online Shopping Environment. Journal of Service Science and Management, 10, 413-424. https://doi.org/10.4236/jssm.2017.105033

[31] Deng, Z., Hong, Z., Ren, C., Zhang, W. and Xiang, F. (2018) What Predicts Patients Adoption Intention toward mHealth Services in China: Empirical Study. JMIR mHealth and uHealth, 6, e172. https://doi.org/10.2196/mhealth.9316

[32] Reiter, L., McHaney, R. and Connell, K.Y.H. (2017) Social Media Influence on Purchase Intentions: Instrument Validation. International Journal of Web Based Communities, 13, 54-72. https://doi.org/10.1504/IJWBC.2017.082719

[33] Deborah, E.R. and Elizabeth, P. (2004) Website Design: Viewing the Web as a Cognitive Landscape. Journal of Business Research, 57, 787-794. https://doi.org/10.1016/S0148-2963(02)00353-3

[34] Hausman, A.V. and Siekpe, J.S. (2009) The Effect of Web Interface Features on Consumer Online Purchase Intentions. Journal of Business Research, 62, 5-13. https://doi.org/10.5267/j.msl.2015.5.002

[35] Richard, M.O. (2005) Modeling the Impact of Internet Atmospherics on Surfer. Journal of Business Research, 58, 1632-1642. https://doi.org/10.1016/j.jbusres.2004.07.009

[36] Bai, B., Law, R. and Wen, I. (2008) The Impact of Website Quality on Customer Satisfaction and Purchase Intentions: Evidence From Chinese Online Visitors. International Journal of Hospitality Management, 27, 391-402. https://doi.org/10.1016/j.ijhm.2007.10.008

[37] Kandampully, K. (2006) The Antecedents of Customer Satisfaction with Online Travel Services: A Conceptual Model. European Business Review, 20, 4-19.

[38] Van Dijk, G., Minochan, S. and Laing, A. (2006) Multi-Channel Consumer Behavior: Online and Offline Travel Preparations. CHI 6th Extended Abstracts on $\mathrm{Hu}$ man Factors in Computing Systems, Montréal, 22-27 April 2006, 1457-1462. https://doi.org/10.1145/1125451.1125719

[39] Dehbashi, S. and Nahavandi, N. (2007) Factors Affecting on Iranian Passengers' Acceptance towards Electronic Ticketing Provided by Airlines. IADIS International Conference e-Society, Lisbon, 3-6 July 2007, 72-80.

[40] Lin, H. (2007) The Impact of Website Quality Dimensions on Customer Satisfaction in the B2C E-Commerce Context. Total Quality Management \& Business Excellence, 18, 363-378. https://doi.org/10.1080/14783360701231302

[41] Chen, H.H. (2008) The Impact of Online Store Environment Cues on Purchase Intention: Trust and Perceived Risk as a Mediator. Online Information Review, 32, 818-841. https://doi.org/10.1108/14684520810923953 
[42] Ahmad, S.N.B. and Razak, A. (2008) Travel Website Adoption among Internet Users in the Klang Valley, Malaysia. Unitar E-Journal, 4, 59-77.

[43] Kiran, R., Sharma, A. and Mittal, K. (2008) Attitudes, Preferences and Profile of Online Buyers in India: Changing Trends, Jul-Sep 2008. South Asian Journal of Management, 15, 55-73.

[44] Kaur, B. and Madan, S. (2013) Factors Influencing Trust in Online Shopping: An Indian Consumer's Perspective. European Journal of Business and Management, 5, 132-138.

[45] Akar, E. and Nasir, V.A. (2014) A Critical Review of Online Consumers' Purchase Intentions. Advances in Business-Related Scientific Research Conference, Venice, 26-28 March 2014, 1-14.

[46] Suki, N.M. (2007) Online Buying Innovativeness: Effects of Perceived Value, Perceived Risk and Perceived Enjoyment. International Journal of Business and Society, 8, 81-93.

[47] Jarvenpaa, S.L. and Todd, P.A. (1997) Is There a Future for Retailing on the Internet? In: Peterson, R.A., Ed., Electronic Marketing and the Consumer, Sage, Thousand Oaks, 139-154.

[48] Brown, L. (1990) Convenience in Services Marketing. Journal of Services Marketing, 4, 53-59. https://doi.org/10.1108/EUM0000000002505

[49] Gehrt, K.C., Yale, L.J. and Lawson, D.A. (1996) The Convenience of Catalog Shopping: Is There More to It Than Time? Journal of Direct Marketing, 10, 19-28.

[50] Doolin, B., Dillon, S., Thompson, F. and Corner, J.L. (2005) Perceived Risk, the Internet Shopping Experience and Online Purchasing Behaviour: A New Zealand Perspective. Journal of Global Information Management, 13, 66-88. https://doi.org/10.4018/jgim.2005040104

[51] Szymanski, D.M. and Hise, R.T. (2000) E-Satisfaction: An Initial Examination. Journal of Retailing, 76, 309-322. https://doi.org/10.1016/S0022-4359(00)00035-X

[52] Kaufman-Scarborough, C. and Lindquist, J.D. (2002) E Shopping in a Multiple Channel Environment. Journal of Consumer Marketing, 19, 333-350. https://doi.org/10.1108/07363760210433645

[53] Khare, A., Singh, S. and Khare, A. (2010) Innovativeness/Novelty-Seeking Behavior as Determinants of Online Shopping Behavior among Indian Youth. Journal of Internet Commerce, 9, 164-185. https://doi.org/10.1080/15332861.2010.529054

[54] Global Online Retailing An Ernst \& Young Special Report (2001). https://www.indiadomain.com/pdf/globalonlineretailing2001.pdf

[55] Brown, M., Pope, N. and Voges, K. (2003) Buying or Browsing? An Exploration of Shopping Orientations and Online Purchase Intention. European Journal of Marketing, 37, 1666-1684. https://doi.org/10.1108/03090560310495401

[56] Yen, H.R. (2005) An Attribute-Based Model of Quality Satisfaction for Internet Self-Service Technology. The Service Industries Journal, 25, 641-659.

[57] Athiyaman, A. (2002) Internet Users' Intention to Purchase Air Travel Online: An Empirical Investigation. Marketing Intelligence and Planning, 20, 234-242. https://doi.org/10.1108/02634500210431630

[58] Raman, M.A. (2003) An Empirical Investigation of Online Consumer Purchasing Behavior. Communications of the ACM, 46, 145-151. https://doi.org/10.1145/953460.953494

[59] Sulaiman, A., Ng, J. and Mohezar, S. (2008) E-Ticketing as a New Way of Buying Tickets: Malaysian Perceptions. Journal of Social Sciences, 17, 149-157. 
https://doi.org/10.1080/09718923.2008.11892644

[60] Cho, Y.C. and Agrusa, J. (2006) Assessing Use Acceptance and Satisfaction towards Online Travel Agencies. Information Technology and Tourism, 8, 179-195. https://doi.org/10.3727/109830506778690795

[61] Taylor, S. and Todd, P.A. (1995) Understanding Information Technology Usage: A Test of Competing Models. Information Systems Research, 6, 144-176. https://doi.org/10.1287/isre.6.2.144

[62] Delafrooz, N., Paim, L. and Khatibi, A. (2011) Students' Online Shopping Behavior: An Empirical Study. Journal of American Science, 6, 137-147.

[63] Alam, S.S. and Sayuti, N.M. (2011) Applying the Theory of Planned Behaviour (TPB) in Halal Food Purchasing. International Journal of Commerce and Management, 21, 8-20. https://doi.org/10.1108/10569211111111676

[64] Kim, H.-B., Kim, T. and Shin, S.W. (2009) Modeling Roles of Subjective Norms and eTrust in Customers' Acceptance of Airline B2C Ecommerce Websites. Tourism Management, 30, 266-277. https://doi.org/10.1016/j.tourman.2008.07.001

[65] Mohammed, A. and Al-Jabari, S.N. (2012) Actual Online Shopping Behavior among Jordanian Customers. American Journal of Economics, 2, 125-129. https://doi.org/10.5923/j.economics.20120001.28

[66] Quintal, V.A., Lee, J.A. and Soutar, G.N. (2010) Risk, Uncertainty and the Theory of Planned Behavior: A Tourism Example. Tourism Management, 31, 797-805. https://doi.org/10.1016/j.tourman.2009.08.006

[67] Chuchinprakarn, S. (2005) Application of the Theory of Reasoned Action to On-Line Shopping. Knowledge Center E-Paper, Bangkok University, Bangkok, 1-7.

[68] Behjati, S., Pandya, S. and Dileep Kumar, M. (2012) Application of Structural Equation Modeling (SEM) to Explain Online Purchasing Intention-An Extension of Theory of Planed Behaviour (TPB). Industrial Engineering Letters, 2, 33-41.

[69] Putit, L. (2008) Consumers' E-Transaction Behaviour Adoption: An Exploratory Study. Journal of Human Capital Development, 1, 41-46.

[70] Kigongo, N.J. (2011) Perceived Usefulness, Perceived Ease of Use, Behavioural Intention to Use and Actual System Usage in Centenary Bank. Master Thesis.

[71] Liebana-Cabanillas, F., Sanchez-Fernandez, J. and Munoz-Leiva, F. (2014) Role of Gender on Acceptance of Mobile Payment. Industrial Management \& Data Systems, 114, 220-240. https://doi.org/10.1108/IMDS-03-2013-0137

[72] Huang, Y.-H. (2009) Applying Theory of Perceived Risk and Technology Acceptance Model in the Online Shopping Channel. World Academy of Science, Engineering and Technology, 53, 919-925.

[73] Ling, K.C., Chai, L.T. and Piew, T.H. (2011) The Effects of Shopping Orientations, Online Trust and Prior Online Purchase Experience toward Customers' Online Purchase Intention. International Business Research, 3, 63-76.

https://doi.org/10.5539/ibr.v3n3p63

[74] Choon, L., Tan, P., Lau, H. and Chai, T. (2010) Investigating the Shopping Orie Nations on On-Line Purchase Intention in the E-Commerce Environment: A Malaysian Study. Journal of Internet Banking and Commerce, 15, 1-22.

[75] Rahman, M., Khan, A. and Islam, N. (2013) An Empirical Study on Revealing The Factors Influencing Online Shopping Intention among Malaysian Consumers'. Journal of Human and Social Science Research, 1, 9-18.

[76] Nayyar, R. and Gupta, S.L. (2011) Determinants of Internet Buying Behavior in India. Asian Journal of Business Research, 1, 53-65. 
https://doi.org/10.14707/ajbr.110011

[77] Gefen, D. and Straub, D.W. (2000) The Relative Importance of Perceived Ease of Use in IS Adoption: A Study of E-Commerce Adoption. Journal of the Association for Information Systems, 1, Article 8.

[78] Straub, D.G. (2000) The Relative Importance of Perceived Ease of Use in IS Adoption: A Study of E-Commerce Adoption. Journal of the Association for Information Systems, 1, 1-28. https://doi.org/10.17705/1jais.00008

[79] Bigne-Alcañiz, E., Ruiz-Mafé, C., Aldás-Manzano, J. and Sanz-Blas, S. (2008) Influence of Online Shopping Information Dependency and Innovativeness on Internet Shopping Adoption. Online Information Review, 32, 648-667. https://doi.org/10.1108/14684520810914025

[80] Jain, P. (2012) Adoption of Online Marketing in Indian Railways. Thesis.

[81] Renny, S.G. (2013) Perceived Usefulness, Ease of Use, and Attitude towards Online Shopping Usefulness towards Online Airlines Ticket Purchase. Procedia-Social and Behavioral Sciences, 81, 212-216. https://doi.org/10.1016/j.sbspro.2013.06.415

[82] Vathianathan, S. and Roy, S.K. (2009) Factors Affecting Consumers' Attitude towards Online Reservation: An Empirical Analysis. Association for Information Systems. AIS Electronic Library, 15, 37-49.

[83] Wen, C., Prybutok, V.R. and Xu, C.Y. (2011) An Integrated Model For Customer Online Repurchase Intention. Journal of Computer Information Systems, 52, 14-23.

[84] Quelch, J. and Klein, L. (1996) The Internet and International Marketing. Sloan Management Review, 37, 60-75.

[85] Keen, P.G.W. (1997) Are You Ready for the "Trust" Economy. Computer World, 31,80 .

[86] Studio Archetype and Cheskin. The Cheskin Research and Studio Archetype/Sapient E-Commerce Trust Study. www.studioarchetype.com/cheskin/html/phase1.html

[87] Reichheld, F.F. and Schefter, P. (2000) E-Loyalty. Harvard Business Review, 78, 105-113.

[88] Wen, I. (2009) Factors Affecting the Online Travel Buying Decision: A Review. International Journal of Contemporary Hospitality Management, 21, 752-765. https://doi.org/10.1108/09596110910975990

[89] Morgan, R. and Hunt, S. (1994) The Commitment-Trust Theory of Relationship Marketing. Journal of Marketing, 58, 20-38.

https://doi.org/10.1177/002224299405800302

[90] Lee, C.H., Eze, U.C. and Ndubisi, N.O. (2011) Analyzing Key Determinants of Online Repurchase Intentions. Asia Pacific Journal of Marketing and Logistics, 23, 200-221. https://doi.org/10.1108/13555851111120498

[91] Chen, C. (2006) Identifying Significant Factors Influencing Consumer Trust in an Online Travel Site. Information Technology and Tourism, 35, 197-224. https://doi.org/10.3727/109830506778690849

[92] Ganguly, B., Dash, S.B. and Cyr, D. (2013) The Influence of Website Characteristics on Trust in Online Travel Portals in India: The Moderating Role of Demographic and Psychographic Variables. Tourism and Recreation Research, 36, 57-68. https://doi.org/10.1080/02508281.2011.11081660

[93] Zhou, K. (2008) Heulla Online Travel: Gaining Market Insight into Hongkong Consumers. Asia Case Research Center, 08/369C.

[94] Cole, P.M. (2002) The Role of Trust in Electronic Commerce in Services. Interna- 
tional Journal of Contemporary Hospital Management, 14, 81-87. https://doi.org/10.1108/09596110210419264

[95] Duarte, S.A. (2013) Factors That Influence the Purchase of Travel Online: A Proposed Model. Thesis.

[96] Bo, X. and Benbasat, I. (2007) E-Commerce Product Recommendation Agents: Use, Characteristics, and Impact. MIS Quarterly, 31, 137-209. https://doi.org/10.2307/25148784

[97] Thamizhvanan, A. and Xavier, M.J. (2013) Determinants of Customers' Online Purchase Intention: An Empirical Study in India. Journal of Indian Business Research, 5, 17-32. https://doi.org/10.1108/17554191311303367

[98] Bauer, R.A. (1960) Consumer Behavior as Risk Taking. In: Hancock, R.S., Ed., Dynamic Marketing for a Changing World, Proceedings of the 43rd Conference of the American Marketing Association, 389-398.

[99] Peter, J.P. and Ryan, M.J. (1976) An Investigation of Perceived Risk at the Brand Level. Journal of Marketing Research, 13, 184-188.

https://doi.org/10.1177/002224377601300210

[100] Lee, M.K.O. and Turban, E. (2001) A Trust Model for Consumer Internet Shopping. International Journal of Electronic Commerce, 6, 75-91. https://doi.org/10.1080/10864415.2001.11044227

[101] Kolsaker, A., Lee-Kelley, L. and Choy, P.C. (2004) The Reluctant Hong Kong Consumer: Purchasing Travel Online. International Journal of Consumer Studies, 28, 295-304. https://doi.org/10.1111/j.1470-6431.2004.00373.x

[102] AlGhamdi, R., Nguyen, A. and Jones, V. (2013) A Study of Influential Factors in the Adoption and Diffusion of B2C E-Commerce. International Journal of Advanced Computer Science and Applications, 17, 34-52.

[103] Almousa, M. (2014) The Influence of Risk Perception in Online Purchasing Behavior: Examination of an Early-Stage Online Market. International Review of Management and Business Research, 3, 779-787.

[104] Rajamma, R.K., Paswan, A.K. and Hossain, M.M. (2009) Why Do Shoppers Abandon Shopping Cart? Perceived Waiting Time, Risk, and Transaction Inconvenience. Journal of Product \& Brand Management, 18, 188-197. https://doi.org/10.1108/10610420910957816

[105] Pavlou, A.P. (2003) Consumer Acceptance of Electronic Commerce: Integrating Trust and Risk with the Technology Acceptance Model. International Journal of Electronic Commerce, 7, 69-103.

[106] Bianchi, C. and Andrews, L. (2011) Risk, Trust, and Consumer Online Purchasing Behavior: A Chilean Perspective. International Marketing Review, 29, 253-276. https://doi.org/10.1108/02651331211229750

[107] Garbarino, E. and Strahilevitz, M. (2004) Gender Differences in the Perceived Risk of Buying Online and The Effects of Receiving a Site Recommendation. Journal of Business Research, 57, 768-775. https://doi.org/10.1016/S0148-2963(02)00363-6

[108] Zaichkowsky, J.L. (1985) Measuring the Involvement Construct. Journal of Consumer Research, 12, 341-354. https://doi.org/10.1086/208520

[109] Michelle, B., Faure, C. and Perrien, J. (1995) Enduring Involvement with Shopping. The Journal of Social Psychology, 135, 17-25. https://doi.org/10.1080/00224545.1995.9711396

[110] Laaksonen, P. (1994) Consumer Involvement: Concepts and Research. Routledge, London. 
[111] Jiang, Z., Chan, J., Tan, C.Y. and Chua, W.S. (2010) Effects of Interactivity on Website Involvement and Purchase Intention. Journal of the Association for Information Systems, 11, 34-59. https://doi.org/10.17705/1jais.00218

[112] Wakefield, L. and Baker, J. (1998) Excitement at the Mall: Determinants and Effects on Shopping Response. Journal of Retailing, 74, 515-539. https://doi.org/10.1016/S0022-4359(99)80106-7

[113] Kim, J., Fiore, A.M. and Lee, H.-H. (2007) Influences of Online Store Perception, Shopping Enjoyment, and Shopping Involvement on Consumer Patronage Behavior towards an Online Retailer. Journal of Retailing and Consumer Services, 14, 95-107. https://doi.org/10.1016/j.jretconser.2006.05.001

[114] Balabanis, G. and Reynolds, N.L. (2001) Consumer Attitude towards Multi-Channel Retailers' Web Sites: The Role of Involvement, Brand Attitude, Internet Knowledge and Visit Duration. Journal of Business Strategies, 18, 105-129.

[115] Griffith, D.A., Krampf, R.F. and Palmer, J.W. (2001) The Role of Interface in Electronic Commerce: Consumer Involvement with Print versus Online Catalogs. International Journal of Electronic Commerce, 5, 135-153.

https://doi.org/10.1080/10864415.2001.11044219

[116] Lockshin, L., Spawton, A.L. and Macintosh, G. (1997) Using Product, Brand, and Purchasing Involvement for Retail Segmentation. Journal of Retailing and Consumer Services, 4, 171-183. https://doi.org/10.1016/S0969-6989(96)00048-3

[117] Choi, S.Y., Choi, B. and Lee, H. (2006) Categorizing Commercial Products for Customer Oriented Online Retailing. Computers \& Industrial Engineering, 51, 90-101. https://doi.org/10.1016/j.cie.2006.07.001

[118] Moital, M., Vaughan, R. and Edwards, J. (2009) Using Involvement for Segmenting the Adoption of E-Commerce in Travel. The Service Industries Journal, 29, 723-739. https://doi.org/10.1080/02642060902720253

[119] Zanna, M.P. and Rempel, J.K. (1988) Attitudes: A New Look at an Old Concept. Cambridge University Press, Cambridge, 315-334.

[120] Fazio, R.H., Ledbetter, J.E. and Towles-Schwen, T. (2000) On the Costs of Accessible Attitudes: Detecting That the Attitude Object Has Changed. Journal of Personality and Social Psychology, 78, 197-210. https://doi.org/10.1037/0022-3514.78.2.197

[121] Zhang, N.L. (2002) Consumer Online Shopping Attitudes and Behaviour: An Assessment of Research. 8th Americas Conference on Information Systems, 508-517.

[122] Gonzalez, A. and Paliwoda, S.J. (2006) Segmenting the Older Consumer for Online Travel. The Marketing Review, 6, 331-348.

[123] Agarwal, R. and Prasad, J. (1998) The Role of Innovation Characteristics and Perceived Voluntariness in the Acceptance of Information Technologies. Decision Sciences, 28, 557-582. https://doi.org/10.1111/j.1540-5915.1997.tb01322.x

[124] Leavitt, C. and Walton, J. (1975) Development of a Scale for Innovativeness. Advances in Consumer Research, 2, 545-554.

[125] Matthews, G., Deary, I.J. and Whiteman, M.C. (2003) Personality Traits. 2nd Edition, Cambridge University Press, Cambridge.

[126] Goldsmith, R.E. (2002) Explaining and Predicting Consumer Intention to Purchase over the Internet: An Exploratory Study. Journal of Marketing Theory and Practice, 10, 22-28. https://doi.org/10.1080/10696679.2002.11501913

[127] Tellis, G.J., Yin, E. and Bell, S. (2009) Global Consumer Innovativeness: Cross-Country Differences and Demographic Commonalities. Journal of International Marketing, 
17, 1-22. https://doi.org/10.1509/jimk.17.2.1

[128] Rogers, E.M. and Shoemaker, F.F. (1971) The Communication of Innovations. Free Press, Glencoe.

[129] Hui, T.K. and Wan, D. (2004) The Role of Consumer Innovativeness in the Adoption of Internet Shopping in Singapore. The Internet Business Review Issue, 4, 25-36.

[130] Sinha, J. (2010) Factors Affecting Online Shopping Behavior of Indian Consumers. Master Thesis, University of South Carolina, Columbia.

[131] Nunnally, J.C. (1978) Psychometric Theory. 2nd Edition, McGraw-Hill, New York.

[132] Fornell, C. and Larcker, D.F. (1981) Evaluating Structural Equation Models with Unobservable Variables and Measurement Error. Journal of Marketing Research, 18, 39-50. https://doi.org/10.1177/002224378101800104

[133] Bagozzi, R.P. and Yi, Y. (1988) On the Evaluation of Structural Equation Model. Journal of Academy of Marketing Science, 16, 74-94. https://doi.org/10.1007/BF02723327

[134] Haykin, S. (2001) Neural Networks: A Comprehensive Foundation. Prentice Hall, Englewood.

[135] Tan, G.W.H., Ooi, K.-B., Leong, L.-Y. and Lin, B. (2014) Predicting the Drivers of Behavioral Intention to Use Mobile Learning: A Hybrid SEM-Neural Networks Approach. Computers in Human Behavior, 36, 198-213. https://doi.org/10.1016/j.chb.2014.03.052

[136] Chong, A.Y.-L., Liu, M.J., Luo, J. and Ooi, K.-B. (2015) Predicting RFID Adoption in Healthcare Supply Chain from the Perspective of Users. International Journal of Production Economics, 159, 66-75. https://doi.org/10.1016/j.ijpe.2014.09.034

[137] Leong, L.-Y., Hew, T.-S., Tan, G.W.-H. and Ooi, K.B. (2013) Predicting the Determinants of the NFC-Enabled Mobile Credit Card Acceptance: A Neural Network Approach. Expert Systems with Applications, 40, 5604-5620.

https://doi.org/10.1016/j.eswa.2013.04.018

[138] Sim, J.J., Tan, G.W.-H., Wong, J.C.J., Ooi, K.-B. and Hew, T.-S. (2014) Understanding and Predicting the Motivators of Mobile Music Acceptance-A Multi Stage MRA-Artificial Neural Network Approach. Telematics and Informatics, 31, 569-584. https://doi.org/10.1016/j.tele.2013.11.005 